\title{
PROTEVS-MED field experiments: very high resolution hydrographic surveys in the Western Mediterranean Sea
}

\author{
Pierre Garreau $^{1}$, Franck Dumas ${ }^{2}$, Stéphanie Louazel $^{2}$, Stéphanie Correard $^{2}$, Solenn Fercocq ${ }^{2}$, \\ Marc Le Menn ${ }^{2}$, Alain Serpette ${ }^{2}$, Valérie Garnier ${ }^{1}$, Alexandre Stegner ${ }^{3}$, Briac Le Vu ${ }^{3}$, Andrea Doglioli ${ }^{4}$, \\ and Gerald Gregori ${ }^{4}$ \\ ${ }^{1}$ Laboratoire d'Océanographie Physique et Spatiale (LOPS), IFREMER, Université de Bretagne Occidentale, \\ CNRS UMR 6523, IRD, IUEM, 29280 Plouzané, France \\ ${ }^{2}$ SHOM, Service Hydrographique et Océanographique de la Marine, 13 Rue de Châtellier, \\ CS592803, 29228 Brest CEDEX 2, France \\ ${ }^{3}$ Laboratoire de Météorologie Dynamique (LMD), CNRS UMR 8539, \\ École Polytechnique, 91128 Palaiseau, France \\ ${ }^{4}$ Institut Méditerranéen d'Océanographie (MIO), Aix-Marseille Université, Université de Toulon, CNRS, IRD, \\ MIO UM 110, 13288 Marseille, France
}

Correspondence: Pierre Garreau (pierre.garreau@ifremer.fr)

\author{
Received: 19 September 2019 - Discussion started: 27 September 2019 \\ Revised: 20 January 2020 - Accepted: 21 January 2020 - Published: 26 February 2020
}

\begin{abstract}
From 2015 to 2018 four field experiments (seven legs) were performed in the Western Mediterranean basin during winter or early spring. The main objectives were the assessment of high-resolution modeling and the observation of mesoscale structure and associated ageostrophic dynamics. Thanks to the intensive use of a towed vehicle undulating in the upper oceanic layer between 0 and $400 \mathrm{~m}$ depth (SeaSoar), a large number of very high resolution hydrographic transects (total length about $10000 \mathrm{~km}$ ) were measured, observing mesoscale dynamics (slope current and its instabilities, anticyclonic eddies, submesoscale coherent vortices, frontal dynamics, convection events, strait outflows) and submesoscale processes like stirring, mixed-layer or symmetric instabilities. When available, the data were completed with velocities recorded by a vessel-mounted acoustic Doppler current profiler (VMADCP) and by surface salinity and temperature recorded by a thermosalinograph (TSG). Classical full-depth CTD (conductivity, temperature, depth) stations were also used, providing the background hydrography of the deeper layers when focusing on peculiar structures. In 2017, a free-fall profiler (MVP-200; MVP moving vessel profiler) was deployed to manage even higher horizontal resolutions. In 2018, another free-fall profiler (a rapidCAST) was tested. When available, biological sensors (chlorophyll $a$, turbidity, dissolved oxygen, etc.) were used. They provided useful complementary observations about the circulation. This dataset is an unprecedented opportunity to investigate the very fine scale processes, as the Mediterranean Sea is known for its intense and contrasting dynamics. It should be useful for modellers (who reduce the grid size below a few hundred meters) and should properly resolve finer-scale dynamics. Likewise, theoretical work could also be illustrated by in situ evidence embedded in this dataset. The data are available through the SEANOE repository at: https://doi.org/10.17882/62352 (Dumas et al., 2018).
\end{abstract}




\section{Introduction}

Progress in numerical modeling and conceptual approaches both emphasized the importance of fine-scale processes in connecting the ocean interior to the atmosphere, driving the energy cascade to small scales and reversely (McWilliams, 2016) shaping the biochemical cycles and biodiversity distribution (Lévy et al., 2012, 2018). For instance, in the northwestern Mediterranean Sea, chlorophyll $a$ filaments near the external boundary of the Northern Current in the Ligurian Sea are generated by frontal instabilities (Niewiadomska et al., 2008), and coherent vortices may act efficiently, both as biological barriers and drivers of plankton diversity (Bosse et al., 2017; Rousselet et al., 2019). As all these scale interactions are ubiquitous, it is of crucial importance to develop an observation strategy to gain insight simultaneously into the large-scale dynamics, the mesoscale processes and the submesoscale processes. Unfortunately, reaching this objective using conventional cruise strategies is not straightforward, leading to a lack of in situ observations of fine-scale processes. Due to their synoptic view, satellite observations partly fill the gap between larger- and finer-scale dynamics. For many years, remotely sensed observations of surface temperature, ocean colors or altimetry exhibit a large spectrum of processes with various cut-off scales (from around $70 \mathrm{~km}$ for the altimetry to some tens of meters for imagery). Some of these limits will be pushed back soon by the future Surface Water and Ocean Topography (SWOT) satellite, which should provide substantial improvement for smallscale processes with a sea surface height signature (d'Ovidio et al., 2019).

The data presented hereafter are a contribution to very high resolution observations of the top oceanic layer and are freely available on the SEANOE repository at: https://doi.org/10.17882/62352 (Dumas et al., 2018). Long transects of the first $400 \mathrm{~m}$ below the surface were sampled with a horizontal resolution on the order of $2 \mathrm{~km}$ in the Western Mediterranean Sea. The hydrographic and dynamics background of this region are given in Sect. 2. The objectives and implementation of the surveys are presented in Sect. 3. The details of the measurements (platforms, sensors, methodology, metrology, data control, ancillary data) are reported in Sect. 4. To illustrate the potential of the dataset, an overview of the observed processes is displayed in Sect. 5. Lessons learned during surveys and summary are displayed in Sect. 6.

\section{Oceanic contexts of the Western Mediterranean Sea}

The Mediterranean Sea is often referred as a "laboratory basin", exhibiting many processes that are met pervasively and are of primary interest in the functioning of the global ocean (Robinson and Golnaraghi, 1994). It thus provides the opportunity to investigate a large panel of oceanic fea- tures in a relatively restrained and accessible area. Therefore, the PROTEVS-MED cruises potentially caught a multitude of physical processes in the Western Mediterranean Sea (Fig. 1).

\subsection{Surface and intermediate circulation}

The basin or sub-basin dynamics is largely driven by the thermohaline circulation. The Mediterranean Sea is a semienclosed evaporation basin, including areas of intermediate to deep convection. Light (fresh) Atlantic water (AW), flowing in through the Gibraltar Strait, generally circulates along the continental slope in both western and eastern basins (Millot and Taupier Letage, 2005). The slope current is unstable along the Algerian Coast and generates anticyclonic eddies, called Algerian eddies (AEs), that spread AW to the southern half of the Western Mediterranean basin, called the Algerian Basin (Escudier et al., 2016a; Puillat et al., 2002). In the northern part of the Western Mediterranean basin, the AW, composed of the eastern Corsica current (ECC) and western Corsica current (WCC), joins the Ligurian Sea to form the Northern Current that flows along the slope until the Balearic Sea (Millot, 1999; Send et al., 1999). The existence and the strength of a return branch of this current along the northern Balearic front (NBF) between the islands of Menorca and Corsica are still under debate, despite the generally accepted concept of a northern (cyclonic) gyre, in agreement with the doming of isopycnals in the central part of this sub-basin. The Levantine intermediate water (LIW) formed in winter in the eastern basin, entering into the Western Mediterranean basin through the Strait of Sicily, follows more or less the same cyclonic circulation pattern (Millot and Taupier Letage, 2005). It spreads out into the northern part of the Western Mediterranean basin between 400 and $800 \mathrm{~m}$ and is found sporadically within the Algerian Basin. In the Western Mediterranean basin, this important water mass, marked by a relative subsurface maximum of temperature and salinity, was already identified as the water type in Sverdrup et al. (1942).

\subsection{Mesoscale structures}

As in the global ocean the mesoscale dynamics is ubiquitous within the Mediterranean Basin; it plays a major role in redistributing water masses and has been evidenced by remote sensing for a long time (Millot et al., 1990). In the Western Mediterranean basin, the first internal radius of deformation is on the order of $6 \mathrm{~km}$ in the northern basin and of $16 \mathrm{~km}$ in the Algerian Basin (Escudier et al., 2016b). It is an indicator of the typical size of the mesoscale activity because the scale of surface-intensified eddy in geostrophic balance is on the order of a few deformation radii. As a result of ocean-atmosphere exchanges, of large structural instabilities or of flow-topography interactions, submesoscale coherent vortices, hereafter referred to as SCVs (McWilliams, 1985), 


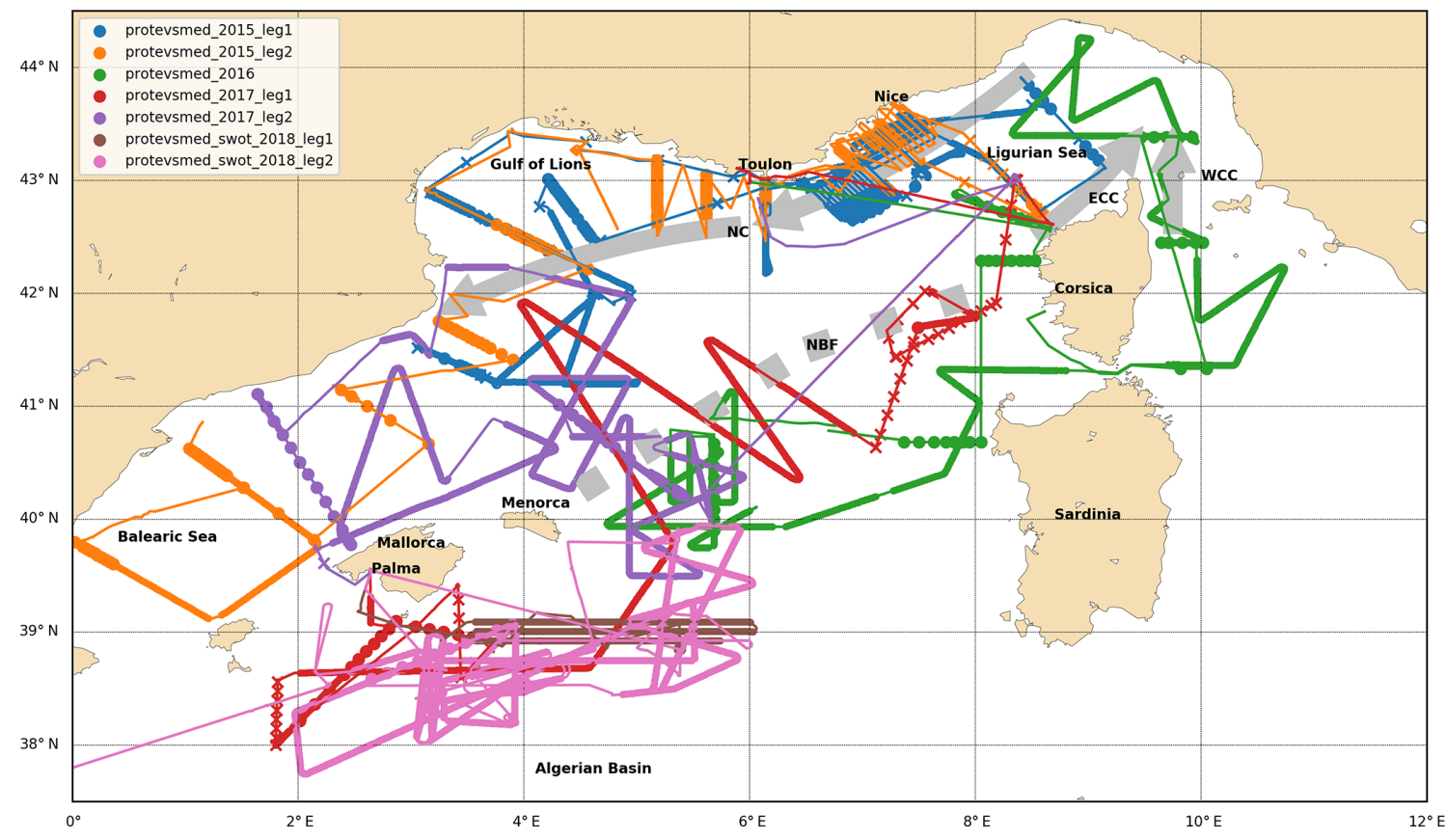

Figure 1. Map of PROTEVS-MED cruises. Dynamical features, northern Balearic front (NBF), eastern Corsica current (ECC), western Corsica current (WCC) and Northern Current (NC) are depicted in grey.

whose sizes are currently close to the local radius of deformation, were observed in the Western Mediterranean (Testor and Gascard, 2003; Bosse et al., 2015, 2016). Eddies, meanders, filaments and fronts are typically smaller than in the world ocean.

\subsection{Submesoscale structures}

There are strong interactions between mesoscale structures, thus generating intense stirring, layered structures and patchy ocean areas. Air-sea exchanges are marked by frequent strong events (tramontane and mistral gusts, for instance in the northwestern Mediterranean basin); they interact with the $\mathrm{NC}$ and mesoscale structures and generate sinks or sources of potential vorticity, thus leading to ageostrophic dynamics (Bosse et al., 2015; Estournel et al., 2016; Giordani et al., 2017; Testor et al., 2018).

Besides this, the northwestern Mediterranean Basin is known to be a place of deep convection events which has been studied for a long time and even taken as one of the paradigms of deep oceanic convection (Medoc Group, 1970; Schott et al., 1996; Houpert et al., 2016; Testor et al., 2018; Marshall and Schott, 1999). Both modeling (Jones and Marshall, 1993, 1997) and observations (Bosse et al., 2016; Margirier et al., 2017) show that deep convection is highly favorable to the production of fine-scale structures at submesoscale levels whether they are due to deepening of the mixed layer during winter or to postconvection restratification.

\subsection{Previous high-resolution observations}

The finest part of the mesoscale dynamics often escapes the usual sampling strategy (CTD - conductivity, temperature, depth - arrays, glider deployments) because of being shortlived, small in size and quickly advected. A development in the last decade of glider fleets revealed nevertheless the mesoscale variability in the Western Mediterranean basin.

Recent field experiments based on the multi-platform integrated monitoring program MOOSE (Coppola et al., 2019) or on the intensive targeted experiment HYMEX (Estournel et al., 2016) have revisited the hydrography and the dynamics of the northwestern part of the Western Mediterranean basin. A strategy of regular and repeated gliders lines as well as dedicated deployments allowed characterizing the variability in the dynamics and describing crossed fine-scale structures. Bosse et al. $(2015,2016)$ inventoried the SCVs and their contributions to water mass redistribution. With data from the same strategy, Margirier et al. (2017) characterized the convection plumes in the Gulf of Lions. Testor et al. (2018) summarized the observations of convection during the dedicated experiment HYMEX. Multi-platform strategies, including gliders, mooring, combined cruises (Ruiz et al., 2009; Pascual et al., 2017; Petrenko et al., 2017; Knoll et al., 2017; Onken et al., 2018; Troupin et al., 2019) or colocation with altimetric tracks (Borrione et al., 2016; Heslop et al., 2017; Aulicino et al., 2018, 2019; Carret et al., 2019), can provide part of the missing synoptic view.

The capability of changing the glider's trajectory at any time has not often been used in a small-scale context be- 
cause its horizontal velocity remains low (in the range of 15$30 \mathrm{~km} \mathrm{~d}^{-1}$ ), preventing any rapid assessment of a detected small structure. Despite this lack of synopticity, Cotroneo et al. $(2016,2019)$ adapted a glider trajectory to a remotely sensed observed Algerian eddy and current. Conversely the SeaSoar horizontal velocity is 10 times faster than the glider one. This towed vehicle can handle a turning radius of $2 \mathrm{nmi}$ (nmi - nautical miles; i.e., gyration speed of $10^{\circ} \mathrm{min}^{-1}$ ) when the ship changes direction. It allows for a strategy based on long exploratory transects as the ship velocity is close to its transit velocity and on intensive sampling of particular detected structures. Due to heavy logistical involvement, the use of SeaSoar remained scarce in the Western Mediterranean Sea. Allen et al. $(2001,2008)$ observed an oblate lens with a $20 \mathrm{~km}$ radius and $150 \mathrm{~m}$ thickness, centered at $250 \mathrm{~m}$ depth during the OMEGA-2 field experiment in fall 1996. Salat et al. (2013) reported SeaSoar transects in the Gulf of Lions after the convection in spring 2009. The SeaSoar was also used during one leg of the ELISA field experiment devoted to the Algerian eddies (Taupier-Letage et al., 2003), but only the mesoscale features have been reported.

A free-fall recovered platform, the moving vessel profiler (MVP-200), has lighter logistics but requires a lower vessel velocity to reach depths equivalent to those reached with the SeaSoar: that is to say 2-4 kn to go $400 \mathrm{~m}$ deep. In the Western Mediterranean Sea, the MVP was deployed during the OSCAHR cruise, allowing a detailed study of a cyclonic structure in the Ligurian Sea (Rousselet et al., 2019) and in situ estimation of the sea surface height for a comparison with along-track satellite data (Meloni et al., 2019).

\section{Objectives and achievement of the field experiments}

The main scientific objectives of the cruises were threefold:

- to assess the large-scale circulation features of the Western Mediterranean basin, evaluating the water masses and the fluxes at different key points in the basin (the Ligurian Sea, the Balearic Sea, the northern Tyrrhenian Sea, the northern Balearic front area and the Algerian Basin), with a goal of assessing of operational numerical simulation of the circulation performed for the navy;

- to identify and follow peculiar mesoscale structures, such as surface eddies, modal structures composed of winter intermediate water (WIW), SCVs, meanders and filaments, and explore their signatures on the sea surface height (altimetry) and their acoustic impact (i.e., through their modulation of the sound propagation speed);

- to observe and characterize the submesoscale dynamics such as ageostrophic stirring, symmetric instabili- ties, mixed-layer instabilities, subduction and convection.

Clearly, the main part of the present dataset is not devoted to tracking any climatic change in water mass properties; the SeaSoar, the MVP and the rapidCAST are rapidly moving platforms, leading to acquiring less-precise temperature, conductivity and above all deduced salinity data than the standardized CTD protocol. MVP and rapidCAST are equipped with unpumped sensors, and the three tools reach high ascending or descending velocity (above $2 \mathrm{~m} \mathrm{~s}^{-1}$ ) that leads to inescapable thermal-lag issues across sharp fronts. Readers interested in this topic should only use the classical CTD station data.

Four cruises were conducted between 2015 and 2018 by the "Service Hydrographique et Océanographique de la Marine" (SHOM) in the Western Mediterranean basin, during winter or early spring, managing mainly the towed undulating vehicle SeaSoar to investigate the subsurface $(0-400 \mathrm{~m})$ layer. When the deployment of this vehicle was either unsafe (over shallow water) or even impossible (due to rough meteorological conditions, breakdown of the winch or vehicle) or when complementary observations were requested (e.g., to go below $400 \mathrm{~m}$ or collect water samples for biochemical analysis), CTD casts were performed instead. On-board routinely acquired data (vessel-mounted acoustic Doppler current profiler - VMADCP - and thermosalinograph - TSG) were also included in this database.

We present here, in a synthetic dataset, all data recorded during the cruises (Fig. 2; Table 1). Complementary data used to design the cruise, to adapt the strategy on field or to interpret results (altimetric tracks, remotely sensed sea surface temperature or chlorophyll $a$ ) are available on CMEMS servers (http://marine.copernicus.eu, last access: 19 February 2020). An eddy detection tool called AMEDA (Le Vu et al., 2017) was also used to detect and track structures during the cruises. Surface and Argo drifters were also dropped during the cruises, and data are available on companion datasets (Table 2).

The first cruise, called PROTEVS-MED 2015_leg1, took place from 7 to 24 January 2015 aboard the R/V Pourquoi Pas? Its main objective was to observe the dynamics of the $\mathrm{NC}$ from the Ligurian Sea to the Gulf of Lions and the associated mesoscale and submesoscale processes. Attention was paid to cross-slope transects in the Gulf of Lions in order to examine the behavior of the Northern Current and the exchanges across the shelf break. An intensive survey of the Northern Current between Toulon and Nice was performed.

The second leg, PROTEVS-MED 2015_leg2, was carried out on the R/V Beautemps-Beaupré from 16 April to 3 May 2015. It started in the Balearic Sea and investigated the slope current from the Ligurian Sea to the Balearic Sea. During this cruise, the SeaSoar trawl failed early, after just three transect acquisitions in the Balearic Sea, describing the hydrology relative to the cyclonic circulation and its associ- 
Table 1. Summary of measured transects, profiles and routinely acquired data. Cumulated length of transects and total numbers of vertical profiles are displayed.

\begin{tabular}{|c|c|c|c|c|c|c|c|}
\hline $\begin{array}{l}\text { PROTEVS- } \\
\text { MED }\end{array}$ & $\begin{array}{l}\text { 2015_leg1 } \\
07-01 / 24-01\end{array}$ & $\begin{array}{l}\text { 2015_leg2 } \\
16-04 / 03-05\end{array}$ & $\begin{array}{l}2016 \\
22-03 / 04-04\end{array}$ & $\begin{array}{l}\text { 2017_leg1 } \\
\text { 27-01/07-02 }\end{array}$ & $\begin{array}{l}\text { 2017_leg2 } \\
11-02 / 23-02\end{array}$ & $\begin{array}{l}\text { swot_2018_leg1 } \\
23-04 / 26-03\end{array}$ & $\begin{array}{l}\text { swot_2018_leg2 } \\
30-04 / 18-05\end{array}$ \\
\hline SeaSoar & $\begin{array}{l}2290 \mathrm{~km} \\
1137 \text { profiles }\end{array}$ & $\begin{array}{l}329 \mathrm{~km} \\
263 \text { profiles }\end{array}$ & $\begin{array}{l}2090 \mathrm{~km} \\
1369 \text { profiles }\end{array}$ & $\begin{array}{l}1858 \mathrm{~km} \\
706 \text { profiles }\end{array}$ & $\begin{array}{l}620 \mathrm{~km} \\
1162 \text { profiles }\end{array}$ & $\begin{array}{l}615 \mathrm{~km} \\
411 \text { profiles }\end{array}$ & $\begin{array}{l}2830 \mathrm{~km} \\
2381 \text { profiles }\end{array}$ \\
\hline MVP & & & & $\begin{array}{l}153 \mathrm{~km} \\
813 \text { profiles }\end{array}$ & $\begin{array}{l}188 \mathrm{~km} \\
708 \text { profiles }\end{array}$ & & \\
\hline rapidCAST & & & & & & $\begin{array}{l}22 \mathrm{~km} \\
92 \text { profiles }\end{array}$ & $\begin{array}{l}167 \mathrm{~km} \\
71 \text { profiles }\end{array}$ \\
\hline CTD & 62 profiles & 151 profiles & 47 profiles & 17 profiles & 27 profiles & 1 profile & 12 profiles \\
\hline LADCP & 56 profiles & 137 profiles & 47 profiles & 18 profiles & 26 profiles & & 3 profiles \\
\hline XBT & 30 profiles & 22 profiles & & 39 profiles & 1 profile & & \\
\hline $\begin{array}{l}\text { VMADCP } \\
38 \mathrm{kHz}\end{array}$ & $2676 \mathrm{~km}$ & & & & & $1071 \mathrm{~km}$ & $4118 \mathrm{~km}$ \\
\hline $\begin{array}{l}\text { VMADCP } \\
150 \mathrm{kHz}\end{array}$ & 3036 km & $3688 \mathrm{~km}$ & & $2705 \mathrm{~km}$ & $5384 \mathrm{~km}$ & $1068 \mathrm{~km}$ & $4128 \mathrm{~km}$ \\
\hline TSG & $3756 \mathrm{~km}$ & $3861 \mathrm{~km}$ & $3744 \mathrm{~km}$ & 2999 km & $3011 \mathrm{~km}$ & $1212 \mathrm{~km}$ & $4984 \mathrm{~km}$ \\
\hline
\end{tabular}

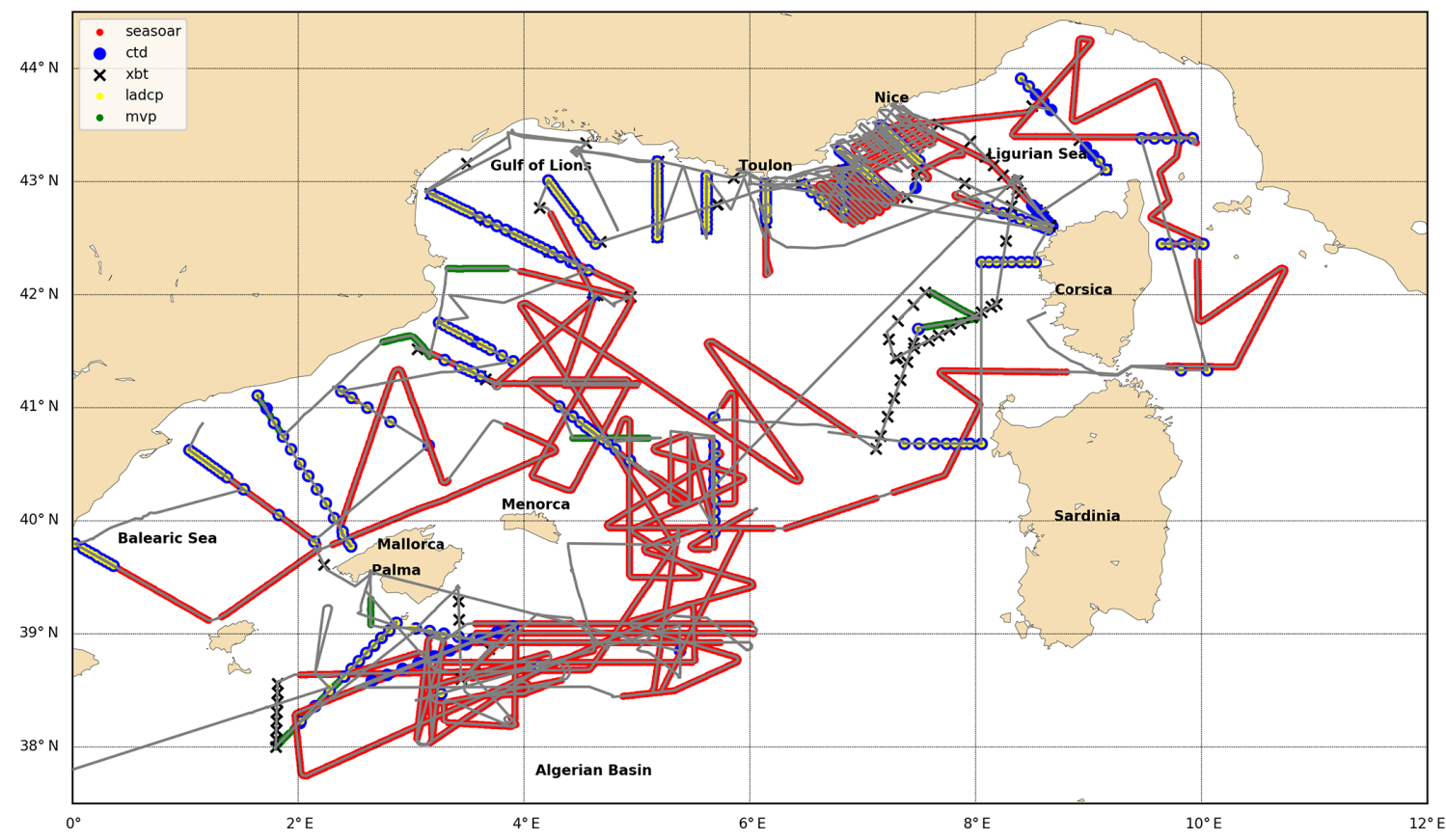

Figure 2. Map of PROTEVS-MED cruises and instruments deployed; TSG is available for all the ship track.

ated mesoscale structures. This therefore led to using mostly CTD stations and VMADCP $150 \mathrm{kHz}$ records. In particular, a dense array of CTD casts were then performed within the Northern Current between Nice and Toulon. The PROTEVSMED 2015_leg2 survey was characterized by a proliferation of jellyfish; the CTD measurements are to be taken with caution, as they caused excessive smoothing of temperature and salinity. When differences that were too large appeared between the values at the ascent and descent, the profiles were flagged with a value of 4 (a bad value that can be corrected).

The second campaign, PROTEVS-MED 2016, took place on the R/V Beautemps-Beaupré from 22 March to 4 April 2016. It was designed to focus on the origin of the $\mathrm{NC}$, where the flows through the Corsica Channel and the 
WCC join. The behavior and the origin of the WCC were also explored along the western coast of Corsica. Besides unveiling part of the complex hydrological structure of the NBF in early spring, the PROTEVS-MED 2016 survey allowed capturing an Algerian eddy in an interaction with the NBF. Garreau et al. (2018) described, in detail, its original double-core structure: a superposition of two water masses of different origin spinning together. The survey provides also scenes of and insights into the way both components of the Northern Current merge together to the north of the Corsica Channel during early spring.

The third campaign PROTEVS-MED 2017 took place from 27 January to 7 February (leg1) and from 11 to 23 February (leg2) aboard the R/V Atalante. This survey was devoted to exploring eddies detected by altimetry in the northern Balearic front and to assessing an eddy-tracking tool (Le Vu et al., 2017). Transects across the northern Balearic front revealed the complexity of this transition zone. In order to escape a rough sea state subsequent to a strong mistral gust, part of the cruise was dedicated to the investigation of the Balearic Sea and the outflow of a coastal fresher and colder water mass from the Gulf of Lions. Back in the deep-sea area, partial convection and WIW formation were recorded. An SCV was thoroughly observed to the north of the Balearic front.

The fourth and last field experiment, PROTEVS-MEDSWOT 2018, was conducted in the framework of SWOT preparatory phase from 23 April to 26 April (leg1) and from 30 April to 18 May (leg2) south from Balearic Islands aboard the R/V Beautemps-Beaupré. The first leg (leg1) gave a general overview of the oceanic situation, followed by a more intensive survey (leg2) planned on the basis of daily release of near-real-time satellite imagery, altimetry and lagrangian analyses, performed on land by using a dedicated package (http://www.mio.univ-amu.fr/SPASSO/ last access: 19 February 2020, as in Nencioli et al., 2011; de Verneil et al., 2017). Satellite data of altimetry, sea surface temperature and ocean color revealed ubiquity throughout the cruise period of very fine oceanic structures such as dipolar structures or tenuous fronts. A special focus was on the region south of Mallorca, where fronts were detected by altimetryderived currents and diagnosis (e.g., Finite Singular Lyapunov Exponents; d'Ovidio et al., 2004) and by contrasting surface chlorophyll $a$ concentrations and confirmed by highfrequency flow cytometry analyses of phytoplankton performed onboard (data not included in the present dataset). A Lagrangian strategy was specifically set up in order to study the structure and growth rate (at $24 \mathrm{~h}$ timescale) of the various phytoplankton groups as defined by flow cytometry measurements as in Marrec et al. (2018). Lastly, it is noticeable that a companion campaign (PRE-SWOT) managed by IMEDEASOCIB was conducted in the same area and during the same period aboard the R/V García del Cid (not included in the present dataset; see Barceló-Lull et al., 2018).

\section{Data, methods and quality controls}

\subsection{CTD casts and LADCP}

The CTD casts were performed with the Sea-Bird SBE-9 instrument mounted in a General Oceanics 12-place rosette frame fitted with 12 Niskin bottles. Sometimes a RDI $150 \mathrm{kHz}$ current profiler was also implemented on the rosette, and then the LADCP (lower acoustic Doppler current profiler) performed measurements during the cast. Standard hydrographic procedures for CTD casts were applied. When available, LADCP recorded data were processed following the inversion method of Visbeck (2002).

\subsection{SeaSoar deployments}

The SeaSoar is a towed undulating vehicle designed and built by Chelsea Instruments. Two Sea-Bird SBE-9 (with SBE3 temperature and SBE-4 conductivity sensors) instruments were mounted on either side of the SeaSoar. When available, a WET Labs WETStar chlorophyll $a$ fluorometer and both the oxygen sensor (SBE-43) and optical-properties sensor (WET Labs C-Star) were deployed. The SeaSoar was trawled at $9 \mathrm{kn}$ by a profiled cable. It undulated between the surface and $400 \mathrm{~m}$ below the surface under optimal conditions, with a horizontal resolution on the order of $2 \mathrm{~km}$. Rough sea states, lateral currents and strong vertical shears can degrade the performance of the vehicle and reduce the vertical range of exploration between 20 and $360 \mathrm{~m}$. As the software allows real-time visualization of the ongoing transect, it is a perfect tool to scan the upper oceanic layer, where mesoscale and submesoscale dynamics are the most intense. A total of $10000 \mathrm{~km}$ of transects crossing numerous and various structures was recorded during the cruises, giving us the unique opportunity to explore fine-scale patterns of the upper layer of the Western Mediterranean basin.

\subsection{MVP deployments}

During PROTEVS-MED 2017 surveys a moving vessel profiler (MVP-200) - a computer-controlled winching system that can deploy and recover a sensor from a ship that is underway - was deployed for finer transects. The sensor was an AML CTD sensor embedded in a free-fall fish. At 2-4 kn, it was possible to monitor the $0-400 \mathrm{~m}$ layer with a horizontal resolution of less than $1 \mathrm{~km}$. To remove spurious salinity values due to bubbles when the instrument is surfacing, the minimum pressure for valid record was set to $1 \mathrm{dbar}$. A peculiar transect was monitored using, successively, SEASOAR, MVP and CTD casts, given the opportunity to compare the three techniques.

\section{4 rapidCAST deployments}

During PROTEVS-MED 2018 a free-fall CTD system, called rapidCAST (Teledyne Marine; http://www.teledynemarine. 
com/rapidcast, last access: 19 February 2020), was tested for three transects near the Balearic Islands. It was equipped with the "rapidCTD - underway profiler", proposed by Valeport. Bluetooth communication allowed real-time evaluation of each profile when the probe surfaced near the ship deck. This system sampled the water layer from 0 to $400 \mathrm{~m}$, with a navigation speed in the range of 5-6 kn and a resolution similar to SeaSoar (about $2 \mathrm{~km}$ ).

\subsection{TSG}

During the cruises, a Seabird SBE-21 thermosalinograph recorded the sea surface temperature and conductivity. The inlet was equipped with an SBE-38 thermometer. The recorded sea surface temperature and salinity contributed to the Global Ocean Surface Underway Data (GOSUD) program (Gosud, 2016). The metrological traceability and the data treatment are insured according to the procedures described in Gaillard et al. (2015), which explains the delayed mode processing of datasets and presents an overview of the resulting quality. The calibrations are complemented with rigorous adjustments on water samples, leading to a salinity accuracy of about 0.01 or less.

\subsection{VMADCP}

The hardware used, its configurations and the way it is used are similar on the R/V Pourquoi Pas?, R/V L'Atalante and $\mathrm{R} / \mathrm{V}$ Beautemps Beaupré. The VMADCPs are the 150 and $38 \mathrm{kHz}$ Ocean Surveyor by Teledyne RDI. They are both monobloc antennas using the beam-forming process to form four beams oriented towards $30^{\circ}$ from the vertical. Nominally, they emitted a ping per second, which allows the ensemble to have less-noisy profiles. Two ensembles are routinely processed:

- a short-term average (hereafter STA) which gathers and averages the pings of a 2 min window and makes an ensemble of at least 120 pings,

- a long-term average (hereafter LTA) made of 600 pings or averaged over $10 \mathrm{~min}$.

The series of geometric transformations necessary to pass from beam coordinates along beam data to absolute geographic coordinate and geophysical velocity are performed thanks to VMDAS software from Teledyne RDI. It combines the position (latitude and longitude) from the DGPS (Differential Global Positioning System) Aquarius and Octans central system with the PHINS inertial navigation system from IXSEA (that provides vessel attitude data: pitch, roll, heaving) to provide synchronized single-ping Earth coordinate data (file.ENX) and short- and long-term ensembles (STA and LTA).

This native format (.STA and .LTA) was also processed with WinADCP in order to extract and provide only signif- icant (i.e., with a satisfactory signal-to-noise ratio) data that are additionally formatted to a text file.

Note that data processed by CASCADE software can be requested from the SISMER repository, collecting and processing progressively all VMADCPs from French research vessels (https://sextant.ifremer.fr/record/ 60ad1de2-c3e1-4d33-9468-c7f28d200305/en/index.htm, last access: 19 February 2020).

\subsection{Data metrological traceability and calibration}

SBE-9 temperature and conductivity sensors deployed on all CTD sensors were calibrated before and after each campaign or at least once a year in the SHOM's thermo-regulated baths, whose temperature can be stabilized to less than $1 \mathrm{mK}$ (peak to peak) during control and calibration operation. Such a procedure allows the monitoring of sensors drifts between calibrations and the detection of anomalies. In the cases in which sensors kept a good linearity, which is the most common, data are corrected with offset-slope coefficients. Figure 3a shows a review of the corrections applied on data at $15^{\circ} \mathrm{C}$, after the calibrations of SBE-3 sensors used for PROTEVSMED campaigns. Figure $3 b$ shows a review of corrections applied at $40 \mathrm{mS} \mathrm{cm}^{-1}$ after the calibrations of SBE-4 sensors.

The temperature of the thermo-regulated bath is monitored with SBE-35, which is used as a laboratory reference temperature sensor. It is linked to the International Temperature Scale of 1990 (ITS-90), thanks to calibrations performed once a year in a triple-point-of-water cell and at the melting point of gallium. These reference cells are regularly calibrated by the French National Metrology Institute (NMI) LNE-CNAM. The calibration expanded uncertainty of SBE3 sensors is between 1.8 and $2.3 \mathrm{mK}$, according to the residual linearity errors of SBE-3 sensors.

The conductivity calibration of SBE-4 sensors is made in the same bath during the temperature calibration. Seawater samples are taken into the bath and tested against Autosal and Portasal salinometers. The calibration procedure and the propagation of uncertainties to the calculated salinities from SBE-9 data are described in Le Menn (2011). Practicalsalinity expanded uncertainty varies from 0.0032 to 0.0034 . In 2015, the SHOM laboratory took part in the JCOMM intercomparison for seawater salinity measurements (JCOMM, 2015), showing that Autosal and Portasal measurements are within \pm 0.001 compared to other participating laboratories. Note that the same process was done in the framework of an international network for the TSG data of the French research vessel (see Sect. 4.5 and Table 2). Unfortunately, the MVP and the rapidCAST sensors were not available for such a common process and were calibrated directly by the constructor, but a comparison with the in situ records with calibrated SBE sensors can be carried out. As the optical properties and oxygen concentration were used as tracers only, no calibration process was performed. 
Table 2. WMO index of Argo float and surface drifters (SVP) dropped during PROTEVS-MED surveys. Surface temperature and salinity recorded by thermosalinograph (TSG) are tagged by ship identifier. All data are available from the CORIOLIS website at: http://www.coriolis. eu.org/Data-Products/Data-Delivery/Data-selection (last access: 19 February 2020) by entering the WMO numbers in the field "Platform codes", adjusting the time period of interest (e.g., 1 January 2018 to 30 June 2019) and clicking on "refresh". The web interface displays the trajectories of the buoys, profilers or TSG and can be used to find additional opportunity data. The data can then be downloaded in NetCDF format.

\begin{tabular}{|c|c|c|c|}
\hline & $\begin{array}{r}\text { ARGO float } \\
\text { WMO identifier: } \\
\text { http://www.ifremer.fr/argoMonitoring/ } \\
\text { (last access: } 19 \text { February 2020) }\end{array}$ & $\begin{array}{r}\text { SVP surface drifter } \\
\text { WMO identification number } \\
\text { (holey-sock depth): } \\
\text { http://www.jcommops.org/dbcp/ } \\
\text { (last access: } 19 \text { February 2020) }\end{array}$ & $\begin{array}{l}\text { TSG thermosalinograph } \\
\text { (platform identifier): } \\
\text { http://www.gosud.org } \\
\text { (last access: 19 February 2020) }\end{array}$ \\
\hline PROTEVS-MED 2015_leg1 & $\begin{array}{l}6901707 \\
6901708\end{array}$ & $\begin{array}{l}6100536(50 \mathrm{~m}) \\
6100537(50 \mathrm{~m}) \\
6100538(50 \mathrm{~m}) \\
6100539(50 \mathrm{~m}) \\
6100540(50 \mathrm{~m})\end{array}$ & FMCY \\
\hline PROTEVS-MED 2015_leg2 & & $\begin{array}{l}6100863(50 \mathrm{~m}) \\
6100864(50 \mathrm{~m}) \\
6100865(50 \mathrm{~m}) \\
6100866(50 \mathrm{~m}) \\
6100867(50 \mathrm{~m})\end{array}$ & FABB \\
\hline PROTEVS-MED 2017_leg1 & $\begin{array}{l}6902764 \\
6902765 \\
6902767\end{array}$ & $\begin{array}{l}6101634(50 \mathrm{~m}) \\
6101639(50 \mathrm{~m}) \\
6101635(50 \mathrm{~m}) \\
6101637(50 \mathrm{~m}) \\
6101636(50 \mathrm{~m}) \\
6101643(50 \mathrm{~m}) \\
6101641(50 \mathrm{~m}) \\
6101647(50 \mathrm{~m})\end{array}$ & FNCM \\
\hline PROTEVS-MED 2017_leg2 & & $\begin{array}{l}6101648(50 \mathrm{~m}) \\
6101633(50 \mathrm{~m}) \\
6101638(50 \mathrm{~m}) \\
6101640(50 \mathrm{~m}) \\
6101632(50 \mathrm{~m}) \\
6101642(50 \mathrm{~m})\end{array}$ & FNCM \\
\hline PROTEVS-MED-SWOT 2018_leg1 & 6902844 & $\begin{array}{r}6101669(50 \mathrm{~m}) \\
6102612(50 \mathrm{~m}) \\
6101677(100 \mathrm{~m}) \\
6102613(100 \mathrm{~m})\end{array}$ & FABB \\
\hline PROTEVS-MED-SWOT 2018_leg2 & & $\begin{array}{l}610167115 \mathrm{~m} \\
610167815 \mathrm{~m} \\
610167215 \mathrm{~m} \\
610261515 \mathrm{~m} \\
610167050 \mathrm{~m} \\
610167450 \mathrm{~m}\end{array}$ & FABB \\
\hline
\end{tabular}



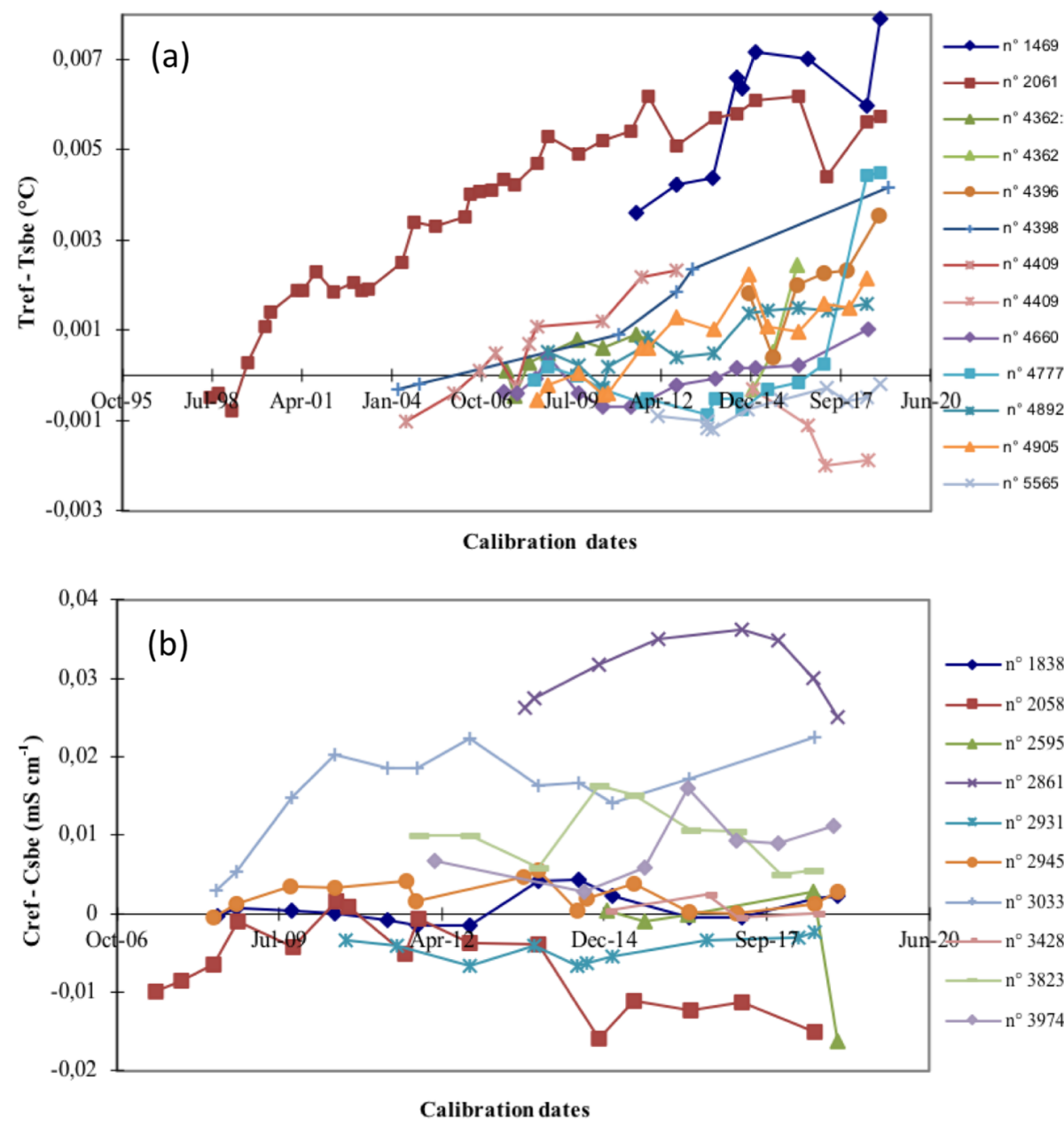

Figure 3. (a) Review of corrections applied on data at $15{ }^{\circ} \mathrm{C}$, after the calibrations of SBE-3 sensors. (b) Review of corrections applied on data at $40 \mathrm{mS} \mathrm{cm}^{-1}$, after the calibrations of SBE-4 sensors.

\subsection{Data processing levels}

Three levels of processing are available for each dataset:

- Level 0 (L0) consists of the direct output of sensors at full temporal resolution.

- Level 1 (L1) displayed data in ASCII (.csv) or netCDF (.nc) files are only processed from the software of the constructor, keeping the full resolution and computing the derived variables into standard units. A recent instrumental system (AML and Valeport probes) directly provides L1 files. L1 files are corrected for eventual drift of sensors.

- Level 2 (L2) is proposed as gridded, controlled and resampled data in netCDF files (.nc). Gridded datasets for salinity and temperature were resampled vertically every meter, removing spikes, spurious values and density inversions when they persist after the first process supplied by the sensor manufacturer. They are then posi- tioned as vertical profiles at the mean geographical position of the ascending or descending record.

Temperature and salinity data were also compared to the historical data in the neighborhood of the profiles or transects using the validated CORA database distributed by the Copernicus Marine and Environment Service (Cabanes et al., 2013; Szekely et al., 2019). PROTEVS-MED data are not yet included in this database but will be transmitted for a future release.

All gridded profiles or transects were plotted for a visual quality check and are available as "quick looks" on the repository. The L1 and/or L2 dataset is released in the present database. L0 data remain available in constructor format upon request to the data-providing institution (SHOM; data-support@shom.fr).

\subsection{Companion datasets}

During the field experiments, surface drifters with holey socks located at $100,75,50$ or $15 \mathrm{~m}$ depth were deployed, 

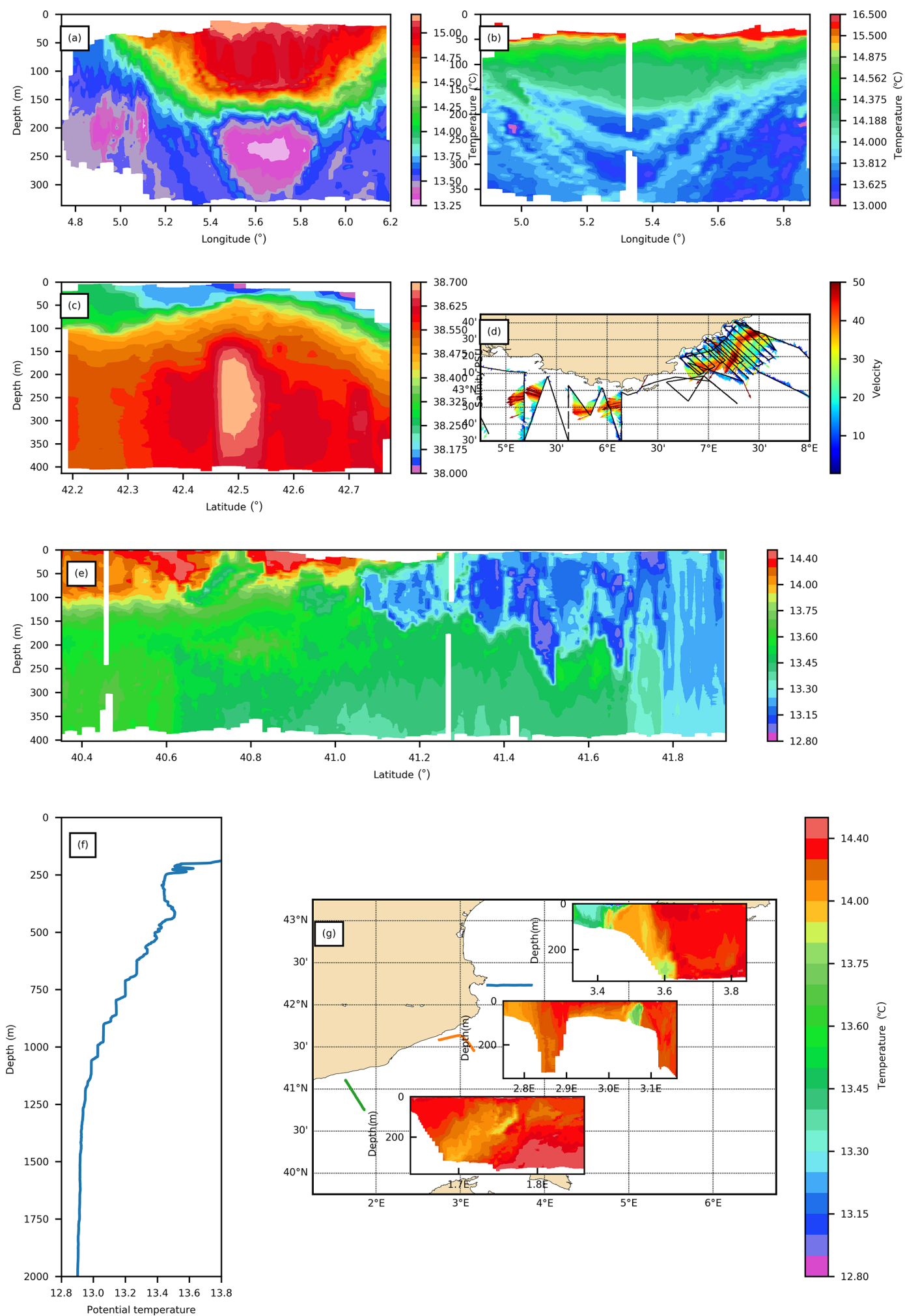

Figure 4. Overview of some transects or profiles recorded during the PROTEVS-MED fields experiments: (a) dual-core eddy in NBF in 2016 $\left(39.96^{\circ} \mathrm{N}, 4.74^{\circ} \mathrm{E}-39.93^{\circ} \mathrm{N}, 6.20^{\circ} \mathrm{E}\right)$, (b) three-layered eddy in Algerian Basin $\left(38.5^{\circ} \mathrm{N}, 4.87^{\circ} \mathrm{E}-38.75^{\circ} \mathrm{N}, 5.88^{\circ} \mathrm{E} ; 2^{2018}\right),(\mathbf{c}) \mathrm{SCV}$ of LIW front of Toulon $\left(42.17^{\circ} \mathrm{N}, 6.14^{\circ} \mathrm{E}-42.78^{\circ} \mathrm{N}, 6.10^{\circ} \mathrm{E} ; 2015\right)$, (d) Northern Current position and intensity (2015), (e) cross-frontal $(\mathrm{NBF})$ transect $\left(40.35^{\circ} \mathrm{N}, 6.43^{\circ} \mathrm{E}-41.92,4.01^{\circ} \mathrm{E} ; 2017\right)$, (f) and staircase structure in temperature front of Sardinia (2016), vein of cold water from the Gulf of Lion in Catalan Sea $\left(40.68^{\circ} \mathrm{N}, 7.5^{\circ} \mathrm{E} ; 2017\right)$. The reader will find similar quick looks of the transects for all the surveys in the data repository. 
given the opportunity at the beginning of their track to perform a Lagrangian survey of observed structures.

A few Argo floats were also dropped and experienced the first PROTEVS-MED dedicated mission with high temporal resolution (daily cycle) and parking depths adjusted to the observations to maintain the drifters as long as possible within the targeted structures (typically $100 \mathrm{~m}$ deep). After the drifter left the structure, it used the usual Argo standard procedure in the Mediterranean (i.e., a $5 \mathrm{~d}$ cycle and a parking depth of $350 \mathrm{~m}$ ). Already stored in dedicated and accessible stable repositories, they can be found using their WMO (World Meteorological Organization) identifiers (see Table 2). Ancillary data can be found on different repositories by selecting dates and locations corresponding to PROTEVS-MED surveys.

\section{Overview of the selected observations}

When deployed together, VMADCP and SeaSoar provided a unique synoptic view along transects. It was also possible to simultaneously observe the density and the velocity fields in the subsurface layer, showing the importance of the geostrophy even at a fine scale (on the order of $10 \mathrm{~km}$ ). The temperature and salinity fields were patchier than expected, but the thermal expansion and the saline contraction coefficient of seawater often compensate for, and lead to, a smoother density (and thus dynamical) field. The structure of observed anticyclonic eddies also appeared more complex than formerly described and was commonly composed of many different water masses. Eddies with similar altimetric or surface thermal signatures can be very different hydrographically. For instance, a dual-core anticyclonic eddy, observed east of the island of Menorca in March 2016 (Fig. 4a), was composed of a superposition of winter intermediate water and Atlantic water, and in May 2018 a three-core eddy was detected (Fig. 4b). The exact process of their formation remains to be investigated. One can invoke the coalescence of pre-existing eddies, the extraction of water masses from neighboring structures or ageostrophic processes. Measurements reveal submesoscale (ageostrophic) dynamics both in the eddy cores (upwelling and downwelling) and at eddy edges (symmetric instabilities, frontogenesis). Intra-pycnocline structures that were subducted, stirred or locally formed were commonly observed at the edge of gyres.

In the Northern Current, stirring appeared in both tracers and velocity fields, and an SCV formed by LIW detached in front of Toulon (Fig. 4c) was observed, as confirmed by observed swirling velocities on VAMDCP records. It was also topped by a surface cyclonic gyre. Currents were routinely recorded, and particular attention was paid to the Northern Current dynamics, as shown Fig. 4d.

The fine-scale structure of the NBF showed the interaction between the front and the SCVs generated in the deep con- vection area. In the NBF, a shift between a surface layer front and a deep front is revealed. As long as most of the experiments presented here were performed during late winter or early spring in the vicinity of deep convection area, they frequently showed small-scale structures that are likely formed by convection. For instance, from the north to the south, in Fig. 4e, one can observe successively the - probably partial convection area, the formation of SCVs composed of WIW in the mesoscale adjustment area around the convection chimney, the surface thermal front and finally a deeper front at $40.6^{\circ} \mathrm{N}$.

Over the abyssal plain near the bottom, the classical CTD station highlighted different Western Mediterranean deep water (WMDW); besides this, under the LIW layer, where the profiles foster a double-diffusion process, staircase structures in temperature and salinity were commonly observed, as in Onken and Brambilla (2003; Fig. 4f).

MVP transects measured in February 2017, in front of Cap de Creus, across Blanes Canyon and off the coast of Barcelona, showed cold water movement along the Catalan shelf and slope (Fig. 4g). The WIW observed along the Catalan slope was relatively fresh and cold water originating from the Gulf of Lion's shelf. The WIW was progressively entrained and mixed with the AW and LIW while flowing southwards in a less intense way than the dense water cascading described by Durrieu de Madron et al. (2013).

Similar and extensive quick looks of all SeaSoar, MVP or rapidCAST transects, and XBT and CTD profiles are plotted and available as additional resources on the data repository.

\section{Data availability}

Data are freely available on the SEANOE repository (https://doi.org/10.17882/62352; Dumas et al., 2018). Some of the data are already being investigated or are in publications; the authors would appreciate collaboration proposals. For an initial overview, quick looks of all SeaSoar, MVP or rapidCAST transects and XBT and CTD profiles are available in catalogues on the repository.

SeaSoar, MVP, rapidCAST, CTD, LADCP and XBT data are stored in both CSV (ASCII) and netCDF files for L1 (directly extracted from the instrument or constructor software) and in netCDF for L2 (resampled every meter) files.

For TSG, the present database provides only L1 files; L2 (validated and resampled data) data are available from the dedicated repository (see Table 2).

For the sake of simplicity, VMADCP files were concatenated over each cruise duration to provide a single file per cruise; for a given cruise, the data are a function of time and depth within the single file dedicated to the cruise.

Data are displayed by cruises and instruments, and the syntax is

instrument_data-type_cruises_starting-date-ofrecord_index.file-type, where 
instruments $=$ ctd,seasoar,ladcp,xbt,rapidcast,mvp, vmadcp_xxx

data-type = "L1" or "L2"

cruises $=$ cruise and leg name

date $=$ the date of the first record in the file

index $=$ sequential index of this kind of profile recorded during the cruise

file-type $=\operatorname{csv}(. \operatorname{csv})$ or netcdf(.nc).

Additionally, data extracted from onboard automatic acquisition are provided in netCDF files for the ship navigation. Future PROTEVS-MED experiments are scheduled, and results will be added to the repository.

\section{Conclusions}

The PROTEVS-MED dataset available through an unrestricted unique repository is an unprecedented opportunity for the community to approach the fine-scale dynamics in the Western Mediterranean Sea and more largely the submesoscale dynamics associated with strong mesoscale dynamics. In the framework of the high-resolution altimetry this dataset can help to characterize the scales of fine-scale structures in the Western Mediterranean Sea and to design combined experiments using high-resolution in situ measurements (SeaSoar or MVP) and altimetry with the future SWOT satellite (d'Ovidio et al., 2019). It also complements the repeated glider lines maintained in the framework of the MOOSE observatory (Coppola et al., 2019) and is useful for designing future combined multi-platform experiments.

During these campaigns, we had the opportunity to deploy different instruments to obtain temperature, salinity and possibly other parameters profiles. Some transects were measured successively using CTD and SeaSoar (all surveys) or using CTD, SeaSoar and MVP-200 (PROTEVS-MED 2017). Being easy to manage, only the rapidCAST has been tested and used, except in 2018, when the SeaSoar failed. It produced a similar result to the SeaSoar in temperature and salinity. The SeaSoar is heavy to manage and needs a consequent research vessel for the winch system, a constant watch on its navigation, and a calm sea state for launch and recovery. Once deployed, the machine can stay at sea for days. Thanks to the required ship velocity (about $9 \mathrm{kn}$ ), the SeaSoar remains a perfect platform for identifying mesoscale structures before examining them in detail. It explores the oceanic surface layer down to $400 \mathrm{~m}$, which is sometimes a bit too short in the Mediterranean context, missing deeper parts of AEs or deep SCVs, but sufficient to describe important surface and subsurface dynamical features. For the same depth range an MVP-200 requires a ship velocity about 2$4 \mathrm{kn}$ and is then more devoted to short transects with higher horizontal resolution. As it is a free-fall platform, its setting is lighter, despite regular inspection of the cable and winch every $10 \mathrm{~h}$. In any case, when exploring a structure in detail, a CTD network remains necessary, at least for having a valid reference level for the thermal wind equation and hydrography.

Despite the suspected lack of accuracy of the sensors due to the velocity of the platforms (SeaSoar, MVP, rapidCAST), this experiment of fast and high-resolution sampling revealed fine oceanic patterns never described before in the Western Mediterranean. In situ observations of ageostrophic dynamics remain rare, and the synergy between these observations and theory, and then between these observations and modeling, should be very fruitful. These data should contribute to the knowledge of small scales and fill some of the gaps in observing systems in the Mediterranean Sea (Tintore et al., 2019). As numerical modeling resolution becomes higher (on the order of few hundred meters), the simulation of submesoscale processes (layering, subduction, stirring, vertical velocities) is therefore expected, and this dataset, providing data at similar scales, is an opportunity to validate the secondary simulated circulation.

Author contributions. SL, SC, PG and FD designed and conducted the field experiments as principal investigators. ML managed the calibration and the metrological traceability of SBE sensors. VG carefully checked the dataset. All co-authors carried out the experiments, participated in the cruise or processed the data. PG and FD prepared the paper and the data, with contributions from all co-authors.

Competing interests. The authors declare that they have no conflict of interest.

Acknowledgements. The authors acknowledge that the French government defense procurement and technology agency (Délégation Générale de l'Armement) funded all the campaigns reported here extensively through Protevs and Protevs II "programme d'étude amont". They thank the technical team at the French Naval Hydrologic and Oceanographic Service (SHOM) and the crews of the French navy ship Beautemps-Beaupré, the R/V Pourquoi Pas ? and the R/V L'Atalante for their contribution to the field experiments.

Financial support. This research has been supported by the Direction Générale de l'Armement (grant no. PEA 082401).

Review statement. This paper was edited by Giuseppe M. R. Manzella and reviewed by two anonymous referees. 


\section{References}

Allen, J. T., Smeed, D. A., Tintoré, J., and Ruiz, S.: Mesoscale subduction at the Almeria-Oran front: Part 1: Ageostrophic flow, J. Marine Syst., 30, 263-285, https://doi.org/10.1016/S09247963(01)00062-8, 2001.

Allen, J. T., Painter, S. C., and Rixen, M.: Eddy transport of Western Mediterranean Intermediate Water to the Alboran Sea, J. Geophys. Res.-Oceans, 113, C04024, https://doi.org/10.1029/2007JC004649, 2008.

Aulicino, G., Cotroneo, Y., Ruiz, S., Sánchez Román, A., Pascual, A., Fusco, G., Tintoré, J., and Budillon, G.: Monitoring the Algerian Basin through glider observations, satellite altimetry and numerical simulations along a SARAL/AltiKa track, J. Marine Syst., 179, 55-71, https://doi.org/10.1016/j.jmarsys.2017.11.006, 2018.

Aulicino, G., Cotroneo, Y., Olmedo, E., Cesarano, C., Fusco, G., and Budillon, G.: In Situ and Satellite Sea Surface Salinity in the Algerian Basin Observed through ABACUS Glider Measurements and BEC SMOS Regional Products, Remote Sens., 11, 1361, https://doi.org/10.3390/rs11111361, 2019.

Barceló-Llull, B., Pascual, A., Díaz Barroso, L., Sánchez-Román, A., Casas, B., Muñoz, C., Torner, M., Alou, E., Cutolo, E., Mourre, B., Allen, J., Aulicino, G., Cabornero, A., Calafat, N., Capó, E., Cotroneo, Y., Cyr, F., Doglioli, A., d'Ovidio, F., Dumas, F., Fernández, J.G., Gómez, Navarro, L., Gregori, G., Hernández-Lasheras, J., Mahadevan, A., Mason, E., Miralles, A., Roque, D., Rubio, M., Ruiz, I., Ruiz, S., Ser-Giacomi, E., and Toomey, T.: PRE-SWOT Cruise Report. Mesoscale and sub-mesoscale vertical exchanges from multi-platform experiments and supporting modeling simulations: anticipating SWOT launch (CTM2016-78607-P), 138 pp., https://digital.csic.es/handle/10261/172644, 2019.

Borrione, I., Falchetti, S., and Alvarez, A.: Physical and dynamical characteristics of a 300m-deep anticyclonic eddy in the Ligurian Sea (Northwest Mediterranean Sea): Evidence from a multiplatform sampling strategy, Deep-Sea Res. Pt. I, 116, 145-164, https://doi.org/10.1016/j.dsr.2016.07.013, 2016.

Bosse, A., Testor, P., Mortier, L., Prieur, L., Taillandier, V., d'Ortenzio, F., and Coppola, L.: Spreading of Levantine Intermediate Waters by submesoscale coherent vortices in the northwestern Mediterranean Sea as observed with gliders, J. Geophys. Res.-Oceans, 120, 1599-1622, https://doi.org/10.1002/2014JC010263, 2015.

Bosse, A., Testor, P., Houpert, L., Damien, P., Prieur, L., Hayes, D., Taillandier, V., Durrieu de Madron, X., d'Ortenzio, F., Coppola, L., Karstensen, J., and Mortier, L.: Scales and dynamics of Submesoscale Coherent Vortices formed by deep convection in the northwestern Mediterranean Sea, J. Geophys. Res.-Oceans, 121, 7716-7742, https://doi.org/10.1002/2016JC012144, 2016.

Bosse, A., Testor, P., Mayot, N., Prieur, L., D’Ortenzio, F., Mortier, L., Goff, H.L., Gourcuff, C., Coppola, L., Lavigne, H., and Raimbault, P.: A submesoscale coherent vortex in the Ligurian Sea: From dynamical barriers to biological implications, J. Geophys. Res.-Oceans, 122, 6196-6217, https://doi.org/10.1002/2016JC012634, 2017.

Cabanes, C., Grouazel, A., von Schuckmann, K., Hamon, M., Turpin, V., Coatanoan, C., Paris, F., Guinehut, S., Boone, C., Ferry, N., de Boyer Montégut, C., Carval, T., Reverdin, G.,
Pouliquen, S., and Le Traon, P.-Y.: The CORA dataset: validation and diagnostics of in-situ ocean temperature and salinity measurements, Ocean Sci., 9, 1-18, https://doi.org/10.5194/os9-1-2013, 2013.

Carret, A., Birol, F., Estournel, C., Zakardjian, B., and Testor, P.: Synergy between in situ and altimetry data to observe and study Northern Current variations (NW Mediterranean Sea), Ocean Sci., 15, 269-290, https://doi.org/10.5194/os-15269-2019, 2019.

Coppola, L., Raimbault, P., Mortier, L., and Testor, P.: Monitoring the environment in the northwestern Mediterranean Sea, Eos, 100, https://doi.org/10.1029/2019EO125951, 2019.

Cotroneo, Y., Aulicino, G., Ruiz, S., Pascual, A., Budillon, G., Fusco, G., and Tintoré, J.: Glider and satellite high resolution monitoring of a mesoscale eddy in the algerian basin: Effects on the mixed layer depth and biochemistry, J. Marine Syst., 62, 7388, https://doi.org/10.1016/j.jmarsys.2015.12.004, 2016.

Cotroneo, Y., Aulicino, G., Ruiz, S., Sánchez Román, A., Torner Tomàs, M., Pascual, A., Fusco, G., Heslop, E., Tintoré, J., and Budillon, G.: Glider data collected during the Algerian Basin Circulation Unmanned Survey, Earth Syst. Sci. Data, 11, 147-161, https://doi.org/10.5194/essd-11-147-2019, 2019.

de Verneil, A., Rousselet, L., Doglioli, A. M., Petrenko, A. A., and Moutin, T.: The fate of a southwest Pacific bloom: gauging the impact of submesoscale vs. mesoscale circulation on biological gradients in the subtropics, Biogeosciences, 14, 3471-3486, https://doi.org/10.5194/bg-14-3471-2017, 2017.

d'Ovidio, F., Fernández, V., Hernández-García, E., and López, C.: Mixing structures in the Mediterranean Sea from finitesize Lyapunov exponents, Geophys. Res. Lett., 31, L17203, https://doi.org/10.1029/2004GL020328, 2004.

d'Ovidio, F., Pascual, A., Wang, J., Doglioli, A. M., Jing, Z., Moreau, S., Grégori, G., Swart, S., Speich, S., Cyr, F., Legresy, B., Chao, Y., Fu, L., and Morrow, R. A.: Frontiers in Fine-Scale in situ Studies: Opportunities During the SWOT Fast Sampling Phase, Front. Mar. Sci., 6, 168, https://doi.org/10.3389/fmars.2019.00168, 2019.

Dumas, F., Garreau, P., Louazel, S., Correard, S., Fercoq, S., Le Menn, M., Serpette, A., Garnier, V., Stegner, A., Le Vu, B., Doglioli, A., and Gregori, G.: PROTEVS-MED field experiments: Very High Resolution Hydrographic Surveys in the Western Mediterranean Sea, SEANOE, https://doi.org/10.17882/62352, 2018.

Durrieu de Madron, X., Houpert, L., Puig, P., Sanchez-Vidal, A., Testor, P., Bosse, A., Estournel, C., Somot, S., Bourrin, F., Bouin, M.N., Beauverger, M., Beguery, L., Calafat, A., Canals, M., Cassou, C., Coppola, L., Dausse, D., D’Ortenzio, F., Font, J., Heussner, S., Kunesch, S., Lefevre, D., Le Goff, H., Martiìn, J., Mortier, L., Palanques, A., and Raimbault, P.: Interaction of dense shelf water cascading and open-sea convection in the northwestern Mediterranean during winter 2012, Geophys. Res. Lett., 40, 1379-1385, 2013.

Escudier, R., Mourre, B., Juza, M., and Tintoré, J.: Subsurface circulation and mesoscale variability in the Algerian subbasin from altimeter-derived eddy trajectories, J. Geophys. Res.-Oceans, 121, 6310-6322, https://doi.org/10.1002/2016JC011760, 2016a.

Escudier, R., Renault, L., Pascual, A., Brasseur, P., Chelton, D., and Beuvier, J.: Eddy properties in the Western Mediterranean Sea from satellite altimetry and a numeri- 
cal simulation, J. Geophys. Res.-Oceans, 121, 3990-4006, https://doi.org/10.1002/2015JC011371, 2016b.

Estournel, C., Testor, P., Taupier-Letage, I., Bouin, M.-N., Coppola, L., Durand, P., Conan, P., Bosse, A., Brilouet, P.-E., Beguery, L., Belamari, S., Béranger, K., Beuvier, J., Bourras, D., Canut, G., Doerenbecher, A., Durrieu de Madron, X., D'Ortenzio, F., Drobinski, P., Ducrocq, V., Fourrié, N., Giordani, H., Houpert, L., Labatut, L., Lebeaupin Brossier, C., Nuret, M., Prieur, L., Roussot, O., Seyfried, L., and Somot, S.: HyMeX-SOP2: The Field Campaign Dedicated to Dense Water Formation in the Northwestern Mediterranean, Oceanography 29, 196-206, https://doi.org/10.5670/oceanog.2016.94, 2016.

Gaillard, F., Diverres, D., Jacquin, S., Gouriou, Y., Grelet, J., Menn, M. L., Tassel, J., and Reverdin, G.: Sea surface temperature and salinity from French research vessels, 2001-2013, Scientific Data, 2, 150054, https://doi.org/10.1038/sdata.2015.54, 2015.

Garreau, P., Dumas, F., Louazel, S., Stegner, A., and Le Vu, B.: High-Resolution Observations and Tracking of a Dual-Core Anticyclonic Eddy in the Algerian Basin, J.Geophys. Res.-Oceans, 123, 9320-9339, https://doi.org/10.1029/2017JC013667, 2018.

Giordani, H., Lebeaupin-Brossier, C., Léger, F., and Caniaux, G.: A PV-approach for dense water formation along fronts: Application to the Northwestern Mediterranean, J. Geophys. Res.-Oceans, 122, 995-1015, https://doi.org/10.1002/2016JC012019, 2017.

Gosud: GOSUD-Global Ocean Surface Underway data, SEANOE, https://doi.org/10.17882/47403, 2016.

Heslop, E. E., Sánchez-Román, A., Pascual, A., Rodríguez, D., Reeve, K. A., Faugère, Y., and Raynal, M.: Sentinel3A Views Ocean Variability More Accurately at Finer Resolution, Geophys. Res. Lett., 44, 12367-12374, https://doi.org/10.1002/2017GL076244, 2017.

Houpert, L., Durrieu de Madron, X., Testor, P., Bosse, A., D’Ortenzio, F., Bouin, M. N., Dausse, D., Le Goff, H., Kunesch, S., Labaste, M., Coppola, L., Mortier, L., and Raimbault, P.: Observations of open-ocean deep convection in the northwestern Mediterranean Sea: Seasonal and interannual variability of mixing and deep water masses for the 2007-2013 Period, J. Geophys. Res.-Oceans, 121, 8139-8171, https://doi.org/10.1002/2016JC011857, 2016.

JCOMM: Pilot intercomparison project for seawater salinity measurements, final report. World Meteorological Organization (WMO), Intergovernmental Oceanographic Commission: JCOMM technical report, no. 84, 2015.

Jones, H. and Marshall, J.: Convection with Rotation in a Neutral Ocean: A Study of Open-Ocean Deep Convection, J. Phys. Oceanogr., 23, 1009-1039, https://doi.org/10.1175/15200485(1993)023<1009:CWRIAN>2.0.CO;2, 1993.

Jones, H. and Marshall, J.: Restratification after Deep Convection, J. Phys. Oceanogr., 27, 2276-2287, https://doi.org/10.1175/15200485(1997)027<2276:RADC>2.0.CO;2, 1997.

Knoll, M., Borrione, I., Fiekas, H.-V., Funk, A., Hemming, M. P., Kaiser, J., Onken, R., Queste, B., and Russo, A.: Hydrography and circulation west of Sardinia in June 2014, Ocean Sci., 13, 889-904, https://doi.org/10.5194/os-13-889-2017, 2017.

Le Menn, M.: About uncertainties in practical salinity calculations, Ocean Sci., 7, 651-659, https://doi.org/10.5194/os-7-651-2011, 2011.

Le Vu, B., Stegner, A., and Arsouze, T.: Angular Momentum Eddy Detection and Tracking Algorithm (AMEDA) and Its Applica- tion to Coastal Eddy Formation, J. Atmos. Ocean. Tech., 35, 739-762, https://doi.org/10.1175/JTECH-D-17-0010.1, 2017.

Lévy, M., Ferrari, R., Franks, P. J. S., Martin, A. P., and Rivière, P.: Bringing physics to life at the submesoscale, Geophys. Res. Lett., 39, L14602, https://doi.org/10.1029/2012GL052756, 2012.

Lévy, M., Franks, P. J., and Smith, K. S.: The role of submesoscale currents in structuring marine ecosystems, Nat. Commun., 9, 1$15,2018$.

Marshall, J. and Schott, F.: Open-ocean convection: Observations, theory, and models, Rev. Geophys. 37, 1-64, https://doi.org/10.1029/98RG02739, 1999.

McWilliams, J. C.: Submesoscale, coherent vortices in the ocean, Rev. Geophys., 23, 165-182, https://doi.org/10.1029/RG023i002p00165, 1985.

McWilliams, J. C.: Submesoscale currents in the ocean, P. R. Soc. A, 472, 20160117, https://doi.org/10.1098/rspa.2016.0117, 2016.

Medoc Group: Observation of Formation of Deep Water in the Mediterranean Sea1969, Nature, 227, 1037-1040, https://doi.org/10.1038/2271037a0, 1970.

Meloni, M., Bouffard, J., Doglioli, A. M., Petrenko, A. A., and Valladeau, G.: Toward science-oriented validations of coastal altimetry: application to the Ligurian Sea, Remote Sens. Environ., 224, 275-288, https://doi.org/10.1016/j.rse.2019.01.028, 2019.

Margirier, F., Bosse, A., Testor, P., L'Hévéder, B., Mortier, L., and Smeed, D.: Characterization of Convective Plumes Associated With Oceanic Deep Convection in the Northwestern Mediterranean From High-Resolution In Situ Data Collected by Gliders, J. Geophys. Res.-Oceans, 122, 9814-9826, https://doi.org/10.1002/2016JC012633, 2017.

Marrec, P., Grégori, G., Doglioli, A. M., Dugenne, M., Della Penna, A., Bhairy, N., Cariou, T., Hélias Nunige, S., Lahbib, S., Rougier, G., Wagener, T., and Thyssen, M.: Coupling physics and biogeochemistry thanks to high-resolution observations of the phytoplankton community structure in the northwestern Mediterranean Sea, Biogeosciences, 15, 1579-1606, https://doi.org/10.5194/bg15-1579-2018, 2018.

Millot, C.: Circulation in the Western Mediterranean Sea, J. Marine Syst., 20, 423-442, https://doi.org/10.1016/S0924 7963(98)00078-5, 1999.

Millot, C. and Taupier-Letage, I.: Circulation in the Mediterranean Sea, in: The Mediterranean Sea, Handbook of Environmental Chemistry, edited by: Saliot, A., Springer, Berlin, Heidelberg, 29-66, https://doi.org/10.1007/b107143, 2005.

Millot, C., Taupierletage, I., and Benzohra, M.: The Algerian Eddies, Earth-Sci. Rev., 27, 203-219, https://doi.org/10.1016/00128252(90)90003-E, 1990.

Nencioli, F., d'Ovidio, F., Doglioli, A. M., and Petrenko, A. A.: Surface coastal circulation patterns by in-situ detection of Lagrangian coherent structures, Geophys. Res. Lett., 38, L17604, https://doi.org/10.1029/2011GL048815, 2011.

Niewiadomska, K., Claustre, H., Prieur, L., and d'Ortenzio, F.: Submesoscale physical-biogeochemical coupling across the Ligurian current (northwestern Mediterranean) using a bio-optical glider, Limnol. Oceanogr., 53, 2210-2225, https://doi.org/10.4319/lo.2008.53.5_part_2.2210, 2008.

Onken, R. and Brambilla, E.: Double diffusion in the Mediterranean Sea: Observation and parameterization of salt 
finger convection, J. Geophys. Res.-Oceans, 108, 8124, https://doi.org/10.1029/2002JC001349, 2003.

Onken, R., Fiekas, H.-V., Beguery, L., Borrione, I., Funk, A., Hemming, M., Hernandez-Lasheras, J., Heywood, K. J., Kaiser, J., Knoll, M., Mourre, B., Oddo, P., Poulain, P.-M., Queste, B. Y., Russo, A., Shitashima, K., Siderius, M., and Thorp Küsel, E.: High-resolution observations in the western Mediterranean Sea: the REP14-MED experiment, Ocean Sci., 14, 321-335, https://doi.org/10.5194/os-14-321-2018, 2018.

Pascual, A., Ruiz, S., Olita, A., Troupin, C., Claret, M., Casas, B., Mourre, B., Poulain, P.-M., Tovar-Sanchez, A., Capet, A., Mason, E., Allen, J. T., Mahadevan, A., and Tintoré, J.: A Multiplatform Experiment to Unravel Meso- and Submesoscale Processes in an Intense Front (AlborEx), Front. Mar. Sci., 4, 39, https://doi.org/10.3389/fmars.2017.00039, 2017.

Petrenko, A. A., Doglioli, A. M., Nencioli, F., Kersalé, M., Hu, Z., and d'Ovidio, F.: A review of the LATEX project: mesoscale to submesoscale processes in a coastal environment, Ocean Dynam., 67, 513-533, https://doi.org/10.1007/s10236-017-1040-9, 2017

Puillat, I., Taupier-Letage, I., and Millot, C.: Algerian Eddies lifetime can near 3 years, J. Marine Syst., 31, 245-259, https://doi.org/10.1016/S0924-7963(01)00056-2, 2002.

Robinson, A. R. and Golnaraghi, M.: The Physical and Dynamical Oceanography of the Mediterranean Sea, in: Ocean Processes in Climate Dynamics: Global and Mediterranean Examples, edited by: Malanotte-Rizzoli, P. and Robinson, A. R., Springer, Netherlands, Dordrecht, 255-306, https://doi.org/10.1007/978-94-0110870-6_12, 1994.

Rousselet L., Doglioli, A. M., de Verneil, A., Pietri, A., Della Penna, A., Berline, L., Marrec, P., Gregori, G., Thyssen, M., Carlotti, F., Barillon, S., Simon-Bot, F., Bonal, M., d'Ovidio, F., and Petrenko, A. A.: Vertical motions and their effects on a biogeochemical tracer in a cyclonic structure finely observed in the Ligurian Sea, J. Geophys. Res., 124, 3561-3574, https://doi.org/10.1029/2018JC014392, 2019.

Ruiz, S., Pascual, A., Garau, B., Faugère, Y., Alvarez, A., and Tintoré, J.: Mesoscale dynamics of the Balearic Front, integrating glider, ship and satellite data, J. Marine Syst., 78, S3-S16, https://doi.org/10.1016/j.jmarsys.2009.01.007, 2009.

Salat, J., Emelianov, M., Frail, E., and Latasa, M.: After deep water formation: sinking and spreading or reorganising phase, including upwelling?, Rapp. Comm. int. Mer Médit, 40, available at: http://www.ciesm.org/online/archives/abstracts/pdf/40/ PG_0175.pdf (last access: 19 February 2020), 2013.

Schott, F., Visbeck, M., Send, U., Fischer, J., Stramma, L., and Desaubies, Y.: Observations of Deep Convection in the Gulf of Lions, Northern Mediterranean, during the Winter of 1991/92, J. Phys. Oceanogr., 26, 505-524, https://doi.org/10.1175/15200485(1996)026<0505:OODCIT>2.0.CO;2, 1996.

Send, U., Font, J., Krahmann, G., Millot, C., Rhein, M., and Tintoré, J.: Recent advances in observing the physical oceanography of the western Mediterranean Sea, Prog. Oceanogr., 44, 37-64, https://doi.org/10.1016/S0079-6611(99)00020-8, 1999.

Sverdrup, H. U., Johnson, M. W., and Fleming, R. H.: The oceans: their physics, chemistry, and general biology, Englewood Cliffs, NJ, Prentice-Hall, 1942.
Szekely, T., Gourrion, J., Pouliquen, S., and Reverdin, G.: CORA, Coriolis Ocean Dataset for Reanalysis, SEANOE, https://doi.org/10.17882/46219, 2019.

Taupier-Letage, I., Puillat, I., Millot, C., and Raimbault, P.: Biological response to mesoscale eddies in the Algerian Basin, J. Geophys. Res.-Oceans, 108, 3845 , https://doi.org/10.1029/1999JC000117, 2003.

Testor, P. and Gascard, J.-C.: Large-Scale Spreading of Deep Waters in the Western Mediterranean Sea by Submesoscale Coherent Eddies, J. Phys. Oceanogr., 33, 75-87, https://doi.org/10.1175/1520 0485(2003)033<0075:LSSODW>2.0.CO;2, 2003.

Testor, P. and Gascard, J.-C.: Post-convection spreading phase in the Northwestern Mediterranean Sea, Deep-Sea Res. Pt. I, 53, 869-893, https://doi.org/10.1016/j.dsr.2006.02.004, 2006.

Testor, P., Bosse, A., Houpert, L., Margirier, F., Mortier, L., Legoff, H., Dausse, D., Labaste, M., Karstensen, J., Hayes, D., Olita, A., Ribotti, A., Schroeder, K., Chiggiato, J., Onken, R., Heslop, E., Mourre, B., D’Ortenzio, F., Mayot, N., Lavigne, H., de Fommervault, O., Coppola, L., Prieur, L., Taillandier, V., Durrieu de Madron, X., Bourrin, F., Many, G., Damien, P., Estournel, C., Marsaleix, P., Taupier-Letage, I., Raimbault, P., Waldman, R., Bouin, M.-N., Giordani, H., Caniaux, G., Somot, S., Ducrocq, V., and Conan, P.: Multiscale Observations of Deep Convection in the Northwestern Mediterranean Sea During Winter 2012-2013 Using Multiple Platforms, J. Geophys. Res.-Oceans, 123, 17451776, https://doi.org/10.1002/2016JC012671, 2018.

Tintore, J., Pinardi, N., Álvarez-Fanjul, E., Aguiar, E., ÁlvarezBerastegui, D., Bajo, M., Balbin, R., Bozzano, R., Nardelli, B.B., Cardin, V., Casas, B., Charcos-Llorens, M., Chiggiato, J., Clementi, E., Coppini, G., Coppola, L., Cossarini, G., Deidun, A., Deudero, S., D’Ortenzio, F., Drago, A., Drudi, M., El Serafy, G., Escudier, R., Farcy, P., Federico, I., Fernández, J.G., Ferrarin, C., Fossi, C., Frangoulis, C., Galgani, F., Gana, S., García Lafuente, J., Sotillo, M.G., Garreau, P., Gertman, I., GómezPujol, L., Grandi, A., Hayes, D., Hernández-Lasheras, J., Herut, B., Heslop, E., Hilmi, K., Juza, M., Kallos, G., Korres, G., Lecci, R., Lazzari, P., Lorente, P., Liubartseva, S., Louanchi, F. Malacic, V., Mannarini, G., March, D., Marullo, S., Mauri, E., Meszaros, L., Mourre, B., Mortier, L., Muñoz-Mas, C., Novellino, A., Obaton, D., Orfila, A., Pascual, A., Pensieri, S., Pérez Gómez, B., Pérez Rubio, S., Perivoliotis, L., Petihakis, G., de la Villéon, L.P., Pistoia, J., Poulain, P.-M., Pouliquen, S., Prieto, L., Raimbault, P., Reglero, P., Reyes, E., Rotllan, P., Ruiz, S., Ruiz, J., Ruiz, I., Ruiz-Orejón, L.F., Salihoglu, B., Salon, S., Sammartino, S., Sánchez Arcilla, A., Sánchez-Román, A., Sannino, G., Santoleri, R., Sardá, R., Schroeder, K., Simoncelli, S., Sofianos, S., Sylaios, G., Tanhua, T., Teruzzi, A., Testor, P., Tezcan, D., Torner, M., Trotta, F., Umgiesser, G., von Schuckmann, K., Verri, G., Vilibic, I., Yucel, M., Zavatarelli, M., and Zodiatis, G.: Challenges for Sustained Observing and Forecasting Systems in the Mediterranean Sea, Front. Mar. Sci., 6, 568, https://doi.org/10.3389/fmars.2019.00568, 2019. 
Troupin, C., Pascual, A., Ruiz, S., Olita, A., Casas, B., Margirier, F., Poulain, P.-M., Notarstefano, G., Torner, M., Fernández, J. G., Rújula, M. À., Muñoz, C., Alou, E., Ruiz, I., Tovar-Sánchez, A., Allen, J. T., Mahadevan, A., and Tintoré, J.: The AlborEX dataset: sampling of sub-mesoscale features in the Alboran Sea, Earth Syst. Sci. Data, 11, 129-145, https://doi.org/10.5194/essd11-129-2019, 2019.
Visbeck, M.: Deep Velocity Profiling Using Lowered Acoustic Doppler Current Profilers: Bottom Track and Inverse Solutions, J. Atmos. Ocean. Tech., 19, 794-807, https://doi.org/10.1175/15200426(2002)019<0794:DVPULA>2.0.CO;2, 2002. 